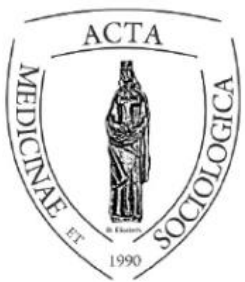

Acta Medicinae et Sociologica (2021)

Vol. 12. No. 32. (112-132)

UNIVERSITY OF

DEBRECEN

FACULTY OF

doi:

HEALTH

https://doi.org/10.19055/ams.2021.05/31/6

NYÍREGYHÁZA

\title{
The possible contexts of inclusion and special educational needs in the light of an international research $^{1}$
}

\section{Az inklúzió és a sajátos nevelési igény lehetséges kontextusai egy nemzetközi kutatás tükrében}

Mihály Fónai ${ }^{1}$, Nóra Barnucz ${ }^{2}$, Lajos Hüse ${ }^{3}$

${ }^{1}$ Egyetemi tanár, Debreceni Egyetem, Egészségügyi Kar, Nyíregyháza, Sóstói út 2.

${ }^{2}$ Egyetemi tanársegéd, Nemzeti Közszolgálati Egyetem, RTK, Budapest, Üllői út 82.

${ }^{3}$ Települések szakmai vezetője, Máltai Szeretetszolgálat, Budapest, Szarvas Gábor u. 58-60.

INFO

ABSTRACT

\author{
Fónai Mihály \\ fonai.mihaly@foh.unideb.hu \\ Barnucz Nóra \\ barnucz,nora@uni-nke.hu \\ Hüse Lajos \\ huselal@gmail.com
}

\section{Keywords}

inclusion, exclusion, especial educational needs (SEN), behavioural problems with learning disabilities

\begin{abstract}
The relationship between school integration and special educational needs (hereinafter: SEN) is analyzed in the framework of an international resarch in this study. In the theoretical part the process of segregation, integration and inclusion is introduced, and also the use of the concepts is dicussed. The integration in the school system means the approach and practice against segregated education of students with disabilities with the aim to eliminate segregated education. SEN is not a diagnostic but an educational concept, and the its special pedagogy and legal term do not coincide. The research was extended to Ukrainian (the Transcarparthian $\mathrm{n}=280)$, Polish $(\mathrm{n}=271)$ and Hungarian students $(\mathrm{n}=552)$. The results show that school inclusion and social support are increased by school success. Success can increase the selfesteem of students with learning problems, which co-occures
\end{abstract}

\footnotetext{
${ }^{1}$ The study - Mihály Fónai (2020): A sajátos nevelési igény és az inklúzió összefüggései nemzetközi kutatás tapasztalatai alapján. [Relationships between special educational needs and inclusion based on the experience of an international research.] In: János Tibor Karlovitz (ed.): Jogok és lehetőségek a társadalomban. [Rights and opportunities in society.] International Research Institute s.r.o. Komárno. pp. 239-255. - was written by its content completion and reconstruction.
} 
with the subjective perception of increasing social support and decreasing exclusion.

\section{Kulcsszavak}

inklúzió, kirekesztés, sajátos nevelési igény (SNI), beilleszkedés, tanulási, és magatartási zavarok

\begin{abstract}
Absztrakt. Tanulmányunkban az iskolai inklúzió és a sajátos nevelési igénye (a továbbiakban: SNI) összefüggéseit vizsgáltuk egy nemzetközi kutatás keretében. Az elméleti részben vázoljuk a szegregációtól az integráción át $a z$ inklúzióig tartó folyamatot, mely alapján vitatott az egyes fogalmak használata. Az iskolarendszerben az integráció a fogyatékossággal élő tanulók szegregált oktatásával szemben kialakult megközelítést és gyakorlatot jelenti, melynek célja az elkülönített oktatás felszámolása volt. Az SNI nem diagnosztikus, hanem iskoláztatási fogalom, és a gyógypedagógiai és a jogi fogalomhasználat sem esik egybe. Kutatásunkba ukrajnai (kárpátaljai, 280 fö), lengyel (271fó) és magyarországi (552 fö) tanulók kerültek. Az iskolai befogadást és a társas támogatást az iskolai sikerek alakítják, növelik. A sikerek képesek a tanulási problémákkal küzdő tanulók önbecsülését is növelni, ami együtt jár a társas támogatás növekedésének és a kirekesztés csökkenésének a szubjektív észlelésével.
\end{abstract}

\section{Introduction}

In our study we examine the effect of and the relationship between school exclusion and special educational needs. The analysis is based on an international project about the school integration of ethnic minority students. ${ }^{2}$ It was a problem-solving and exploratory research that influenced the way of sample selection as well. The correlation between school performance and social differences has been covered in a number of domestic and international studies (Andor 2001; Kertesi-Kézdi 2012). The research, introduced in this study, represents a step forward in the implementation of inclusive school practice in several areas and aspects, since in addition to academic outcomes it also includes a subjective indicator of feelings of well-being, inclusion, rejection and school public activity (Hüse et al. 2014; Zolnai et al. 2016; Cséke-Fónai 2018; Fónai-Hüse 2018). In addition to school settings, participants from social institutions in order to detect inclusion and exclusion and to explore the factors influencing them also used the questionnaire (HüseHorváth 2018). In our research, inclusion was studied by the children's situation which was experienced subjectively. The questionnaire, which was

\footnotetext{
2 „How to help children from families of ethnic minorities in the adaptation to school in V4 countries", an international project by Visegrad Fund, ID 11410116
} 
improved during the project, was responded by Hungarian $(\mathrm{n}=552)$, Polish $(\mathrm{n}=271)$ and Transcarparthian $(\mathrm{n}=280)$ students from classes five to eight. In the questionnaire, the types of special educational needs (hereinafter: SEN) and behavioural problems with learning disabilities (hereinafter: BPLD) defined by the academic literature and Hungarian legislation - were named in a way that students could choose from them by self-classifying and characterize themselves, moreover the language was adjusted to the age group. The students' responses show that there is a significant relationship between self-esteem, social support, exclusion-inclusion, as well as the participationfrequency of SEN and LBP disorders. Our previous analyses also indicated that school success and supportive school atmosphere have a positive effect on selfesteem and social support, which also reduce exclusion and its perception by students (Fónai-Hüse 2018; Zolnai et al. 2016). The main topic of the research was to explore the relationship between SEN and inclusion with the aim to detect the factors and phenomena that support the inclusion of students with SEN.

\section{Theoretical and research background}

In our study, two closely related issues and phenomena like special educational needs and inclusion are studied, and extended to the relation between them. Inclusion is meant to be the broader concept, since 'inclusion', which is a principle or a social and educational philosophy and practice, partly means educational practice and procedure related to students with 'special educational needs'.

The studied phenomenon, inclusion, means social and educational practice as opposed to exclusion, and has a significant academic literature in itself. At the same time, the appearance and the use of the term itself (Papp 2012; Szabó 2015) indicates that inclusion and exclusion cannot be limited to education only. Moreover, these phenomena and processes are closely linked to segregation and discrimination, or to the selectivity of the education systems (Schiffer 2008; Fejes-Szücs 2018). It may also occur that different disciplines take different approaches, or the processes of exclusion are often interpreted in the context of segregating processes, or the phenomena of inclusion is explained in the context of integrating processes to face segregation.

We consider it important to note that the phenomenon of exclusioninclusion can be examined from the aspect of psychology, social psychology, educational theory, philosophy, political science, sociology, and economy. In this study the aspect of sociology is emphasized while focusing on a more 
general approach towards segregation and exclusion, as well as integration and inclusion, and in particular the phenomenon of inclusion-exclusion in education (Schiffer 2008).

"Társadalmi kirekesztés" is the Hungarian translation of the term "social exclusion", which, in its present meaning, was first used in 1974 by René Lenoir. In his interpretation this term meant the exclusion from the system of social protection. In the course of the term's usage, the pursuit of scientific understanding and political activity can be observed from the very beginning (Hüse-Molnár 2017: 59; Schiffer 2008). The attempts to conceptualize the term indicate a broader approach, which has been already mentioned, since economic, social and political exclusions also exist (Peace 2001). Other authors write about exclusion from the labour market, regular work, adequate housing, and community services (Rodgers 1995).

The problems of social exclusion also relate to the operation of the mechanism that maintain and reproduce social inequalities. Inequalities cannot change without modifications in the education system, and the question is to what extent education contributes to the reduction or the maintenance of inequalities. At the same time, the functioning of the school system is affected by more general processes of exclusion, which contribute to the persistence of inequalities (Hüse-Ceglédi 2018). These mechanisms are economic, institutional, cultural and social exclusions, as well as spatial exclusion, and segregation. This approach also shows that the processes of exclusioninclusion in the school and education system can be interpreted in a more general, structural systematic context, and exclusion-inclusion does not exclusively derive from the internal functioning of school.

The more general mechanisms of exclusion-inclusion, if we focus on the school system, the functioning of schools, and inclusion, can also be explained in the context and framework of integration-inclusion, as integration is a mechanism against exclusion. In the school system, integration means an approach and practice developed against segregated education of students with disabilities, with the aim to eliminate segregated education (Csányi 2001; Bánfalvy 2008; Szabó 2015). This is the 'point' where the focus is on the reception and integration of the segregated groups of students. For example, students with disabilities, or excluded/segregated students, who had been excluded from the previous system of education, therefore the processes of integration and inclusion as well as the education policy and educational practices are interlocked with the 'reception and inclusion' of students with 
disabilities or students with 'special educational needs' (SEN) (Csányi 2001, 2003; Pető 2003).

The process of changes in educational practice related to integration is captured by Csányi (2001: 233). The previous, segregated education has been replaced by local integration, which places groups of disabled and nondisabled students separately but in one institution. The next level is social integration, which enables integration outside the classroom (teaching), and then comes the functional integration, which means meaningful co-education, and its two different levels are reception, also known as integration, and acceptance, also known as inclusion. In addition, spontaneous integration can be developed, which means the unconscious placement of children with disabilities in a public institution, without special organizational help, depending on the teachers' goodwill. Integration on school level itself means that disabled and non-disabled children are educated together in a classroom by reducing and eliminating their isolation, and in the case of inclusion the sense of belonging to a common group is realized, these are inclusive schools', which are characterized by ability-centricity and the recognition and removal of the barriers (Bánlaky 2008: 17).

The relationship between the concept of integration and inclusion is not only important for the scientific severity and the use of the clear concept, but it also affects the goals of educational policy and practice, as well as the way schools operate (assuming that there is not only a difference in terminology but also in content). Regarding the possible relationship between integration and inclusion, Papp (2012: 299-300) refers to the possible synonymous expressions, the confrontation of the concepts (practices), the integration without inclusion, the inclusion as "purified" integration, and the inclusion as optimized, extended integration. The latter is based on the concept of "Salamanca Theses", according to which inclusive pedagogy recognizes children's differences and builds on them (Papp 2012; Schiffer 2008).

The results of the empirical researches show that children perform better at the level of knowledge and socially in an integrated or inclusive environment, since inclusive education makes the use of the educational resources more effective and has a positive effect on social relationships, friendships, social competences, and the communication skills of children with disabilities in inclusive settings (Pető 2003).

The process leading to the development and spread of inclusive pedagogy and school practice is presented by Szabó (2015). The terminology of each model, political goals, social image, adult, school, family and child image are 
compared by him based on the analysis of the national and international academic literature. These models range from the medical-biological model through the acceptance of special educational needs to the approach of integration and in the years of 2000s the process until the approach of inclusion is presented with significantly different goals, childhood images, institutional structures and practices (Szabó 2015: 334-340). The bio-psycho-social model with a competence-oriented perspective was spread to the 2010s. In its terminology, the definitions of a child with special educational needs, a person with disability are used, and its social image is characterized by full integration. Its school image is characterized by the elimination of the segregating institutional system, the creation of the least restrictive environment, the reduction of drop-out rates, inclusive education, the inclusive skill of the two types of institutions, and the implementation of education for all children with disabilities (developmental school education) (Szabó 2015: 340).

As it can be seen, the institutional structure of the education of students with disabilities and the applied pedagogical methods are a crucial issue for school integration and inclusion. Not only education has moved towards integration and inclusion, but the term of disability, perception of people, students with disabilities and the terminology used itself have changed a lot. Some of the terminology issues are related to the naming of people with disabilities, which is connected with the interpretations and school programs of disability and special educational needs (SEN). There are countries - where the term of SEN means people with disabilities, where the proportion of SEN is low but the proportion of the separately qualified students is high, and the proportion of the populations of SEN and the integrated ones is high. However, the difference in the proportion of the participants in segregated training is smaller between most countries than in the proportion of SEN (Bánfalvy 2008).

Regarding the use of words, Csányi argues in favour of 'disabled' and 'person with special needs', or 'special needs person, student, or child' (Csányi 2008). Another interpretation problem is that the widespread SEN is not a diagnostic category but a collective concept, and by applying it, additional rights and budgetary resources are provided for disabled children and students, i.e. the pedagogical and special pedagogical professional content, which was used earlier in a narrower sense, has expanded due to the provision of equal opportunities (Mesterházi 2007). Other authors also point out that the expression of special educational need is not a diagnostic but an educational 
concept; moreover, the use of its special pedagogy and legal term (in the Public Education Act) is not completely coincided (Bodrogai et al. 2012).

In addition to the terminological and structural issues outlined, it is important to clarify other concepts. The mostly consensual interpretations in the academic literature (2002: 160-62) are summarized by Gabriella Papp. Disability is a basic concept of special education, a set of attributes created by a change in biological status, and due to this, children are included in special education (it does not have a standardized meaning, according to the author's interpretation it means irreversible damage, harm, defect). In the case of learning disabilities, the emphasis is on the ability to learn, on learning difficulties appearing in various forms of children with learning difficulties. In the case of special educational needs, Papp suggests that this term has become a general collective term instead of the term of disability. Integration means joint education, the reception of a child happens in such a way that there is no real change in pedagogical strategy on the part of the majority school, the special educator is responsible for ensuring of special educational needs, while inclusive pedagogy can be interpreted as a reform of school transformation. Because of this school becomes suitable to meet the educational needs of each child.

\section{Research sample and methods}

The database analyzed in our study is based on a survey carried out in two waves in three countries as a part of an international project. The project was organized by the University of Zielona Góra, whose colleagues developed the Questionnaire of School Life (QSL). Twelve items of the questionnaire measure the experience of self-esteem (social classification), acceptance and social support, and exclusion in three subscales (Farnicka et al. 2014). This questionnaire was further developed to measure socio-demographic background and other phenomena as well:

- students' self-assessment,

- QSL,

- barriers to learning,

- supportive relationships,

- successes and failures,

- settlement, family background and household,

- religiousness,

- ethnicity. 
The self-administered questionnaire was interviewed in Poland $(n=271)$, Hungary $(n=552)$ and Ukraine (Transcarparthia $n=280$ ), among students from 5 to 8 classes. No representative sampling procedure was validated for creating the samples, which affects the generalizability of the results, but they are suitable for an exploratory approach to the studied phenomena. During the planning of the problem-solving and exploratory research, we tried to develop quota samples in the area of the institutions participating in the research. Due to this partly urban schools and urban schools from agglomeration were included in the Polish sample, and the family background of the students from urban schools represents families with high status. In the Hungarian subsample, schools from the agglomeration of the University of Debrecen were selected taking into account the composition of the maintainers. Denominational maintainers, church-run schools, contributed to the data collection after being informed about the aims of the research and the questionnaire. However, due to the expectations and scruples of the nondenominational maintainer, (a cluster of state-run schools called KLIKK), the research could be carried out in a school formerly run by a municipal local government. For this reason, and due to the peculiarities of the region, mostly students from church-run school coming from low-status families were included in the Hungarian sub-sample. In the case of the Transcarparthian subsample, those Hungarian-language schools were included in the sample where the proportion of Roma pupils was high, and the composition of the Transcarparthian sample was the closest of the three sub-samples to the basic population. During data collection, we asked for the consent of the students' parents so that their children could answer the questionnaire. In addition to the conditions influencing the sample selection, an exploratory research was also planned because of the research topic, since, to the best of our knowledge, any research with a similar purpose or topic has hardly been done before. ${ }^{3}$

In the present study, we analyze the 'barriers to learning', thus the block of questions developed to measure 'learning problems' (See Appendix 1) is introduced in more details. To formulate the question block, the National Public Education Act (CXC of 2011) and the analyses in the academic literature were taken into account (Mesterházi 2006; Bodrogai et al. 2012). We tried to make students understand the issue, without making it unpleasant or offensive for them. In order to ease the weight of the problem perceived by the

\footnotetext{
${ }^{3}$ The questions - we studied - are also affected by Csányi 2001; Pető-Ceglédi 2012; Pongrácz 2013.
} 
learner, the form of the question was also suitable for them to express that they did not have such a problem or, if they had had before, they already managed to solve them. While processing the results, this issue was analyzed in three forms. The answers to the original question were transcoded several times, the responses were separated into two options at first (with or without such learning problems), and then the new variable was transformed based on the participation-frequency and co-occurrence of SEN and BPLD. The results of this two, transcoded variables are presented in the empirical part of this study.

\section{Results}

In our study, the relationship between special educational needs and school inclusion is analyzed. Therefore, we asked about the factors that students perceived subjectively that how difficult it was for them to go to school and study. We focused on the students' subjective perception, although it is not the same in the case of a learning problem or a disorder diagnosed by the experts. The results show that there is a significant difference between the diagnosis made by the experts and the subjective problem perception. Not to mention the problems which actually affect studying. In general, the degree of learning difficulty diagnosed by the experts is much lower than the students' subjective assessment, although the Polish subsample differs.

In the present framework, we focus primarily on 'classroom, school' factors. Based on our previous analyses, we found that inclusion, support, and self-esteem are increased by school success while exclusion is reduced by it (Fónai-Hüse 2018). Therefore, the effects of these factors as well as the gender differences are interpreted, while the effects of the family background and ethnicity are not examined.

In the Transcarparthian sample self-esteem, social support, and their experience were also increased by school success, whereas failure had a significant effect on exclusion, individual experience of exclusion was increased by the failures students have experienced. However, success alone was not accompanied by decreasing exclusion, which was explained by 'outof-school' and structural processes (Cséke-Fónai 2018). The tool for the measurement (the complete questionnaire and the scale of the QSL) was adapted to other, partly non-school groups by the members of our research group. In connection with school risk behaviour, it was found that school effectiveness and successfulness also protect against various health-damaging behaviours. The better someone performs at school, the less likely he/she becomes an alcohol or drug user or live with a harmful passion for smoking 
(Balogh-Hüse 2017: 111). Similar phenomena can be observed amongst the resilient Roma students living in vocational colleges. In the dimension of selfesteem, as it was expected, there was a significant correlation with the indicators of the school performance and the indicator of relative self-esteem. Correlations are presumably interlocked to form a system where better academic outcomes and their steadiness are the source of better self-esteem, which in turn has a positive effect on the learner's self-esteem (Hüse-Ceglédi 2018: 119). Examining the attitudes of the majority of primary school children towards children with special educational needs, Pongrácz finds that the positive attitude is more typical among the students with higher self-esteem (Pongrácz 2013), while our own researches show that self-esteem is significantly boosted by school success. Hereinafter we first examine the existence of problems that make it difficult for students to learn and go to school (Table 1).

Table 1: Do you have a problem that makes difficult for you to study and go to school - by country (more options to select - \%)

\begin{tabular}{|l|c|c|c|c|}
\hline & Transcarpathia & Poland & Hungary & P \\
\hline Hearing impairments & 9,3 & 32,8 & 8,2 & 0,000 \\
\hline Vision impairments & 18,6 & 40,6 & 22,5 & 0,000 \\
\hline $\begin{array}{l}\text { Physical disability/motor } \\
\text { impairments }\end{array}$ & 6,4 & 34,3 & 8,0 & 0,000 \\
\hline $\begin{array}{l}\text { Speech disability, speech } \\
\text { impairments }\end{array}$ & 9,6 & 37,6 & 8,0 & 0,000 \\
\hline Difficulties with reading & 31,8 & 39,9 & 15,6 & 0,000 \\
\hline Difficulties with writing & 24,3 & 41,7 & 14,9 & 0,000 \\
\hline Difficulties with counting & 34,3 & 36,5 & 18,8 & 0,000 \\
\hline $\begin{array}{l}\text { I make friends hard, I don't like } \\
\text { to talk or play with others }\end{array}$ & 21,1 & 22,5 & 10,7 & 0,000 \\
\hline
\end{tabular}

Source: own data collection

The issues regarding special educational needs (SEN) and behavioural problems with learning disabilities (BPLD) - as we have indicated - were formulated in a way the students could understand them. Learning problems deriving from organic origin, complex learning disabilities ('dys'), questions concerning the difficulty of integration and the answers to them are included in Table 1. It is obvious that there are significant differences for all possible problems, with exceptionally high Polish data. This can mostly be explained 
by the effect of the research type on the sampling method, and that is why the generalization of the differences requires a great care. The Polish students are from elite metropolitan schools and partly from art schools, which partly explains the high level of learning problems they have indicated. In addition, a much higher proportion of Polish students reported that they had a certificate from an expert about a learning problem. 9.5\% of the Transcarparthian students, $22.5 \%$ of the Polish students and $8.3 \%$ of the Hungarian students have a proof of their own learning problems (the difference is significant $\mathrm{p}=0,000$ ). The higher number of Polish students' 'proved' learning problems can also be explained by the metropolitan environment and the characteristics of schools (elite schools, parents' exceptionally high qualification).

The differences between the Hungarian and the Transcarparthian students are smaller in terms of the problems they have indicated, the problems deriving from organic origin occur in almost similar proportions, while, in the case of the complex learning disabilities and integration difficulties one and a half or double amount of differences can be observed. In the case of the problems deriving from organic origin, cross-tabulation analyses show that there are no differences between genders, or between the students with different family backgrounds (parents' qualification), and their ethnicity. However, among the type of partial learning ability disorders ('dys') a significant difference can be observed, from these the differences between boys and girls are presented in (Table 2).

Table 2: Do you have a problem that makes difficult for you to study and go to school - by gender (more options to select - full sample \%)

\begin{tabular}{|l|c|c|c|}
\hline & Boys & Girls & P \\
\hline Hearing impairments & 12,7 & 15,5 & ns. \\
\hline Vision impairments & 20,4 & 30,4 & 0,000 \\
\hline $\begin{array}{l}\text { Physical disability/motor } \\
\text { impairments }\end{array}$ & 14,7 & 13,3 & $\mathrm{ns.}$ \\
\hline $\begin{array}{l}\text { Speech disability, speech } \\
\text { impairments }\end{array}$ & 14,5 & 16,4 & $\mathrm{ns.}$ \\
\hline Difficulties with reading & 24,7 & 25,7 & $\mathrm{~ns}$. \\
\hline Difficulties with writing & 27,0 & 20,8 & 0,039 \\
\hline Difficulties with counting & 24,5 & 28,9 & $\mathrm{~ns}$. \\
\hline $\begin{array}{l}\text { I make friends hard, I don't like to } \\
\text { talk or play with others }\end{array}$ & 14,5 & 17,6 & $\mathrm{ns.}$ \\
\hline
\end{tabular}


Among the disabilities deriving from organic origin, vision impairments are significantly higher among girls. Although among learning disabilities there is a significant difference only writing disorder, several boys have indicated that they have writing difficulties, while there were two other learning disabilities among girls at a slightly higher rate, similarly to the integration and behavioural disorders. Based on the students' perception of the subjective problem, every four student may be involved, which far exceeds the proportion of students that have been diagnosed by experts. As we have already pointed out, a lack of diagnosis can depend on a number of factors; even if a committee of experts has not diagnosed some pupils with a learning problem (disability) or disorder, they may feel that something affects their school performance, or it can make it difficult for them to learn and go to school. The question is how this affects their school performance (Table 3).

Table 3: Do you have a problem that makes difficult for you to study and go to school - by the students' school performance (more options to select) (\%)

\begin{tabular}{|l|c|c|c|c|c|}
\hline & $\begin{array}{c}\text { Worse than } \\
\text { the average }\end{array}$ & Average & Good & $\begin{array}{c}\text { Very } \\
\text { good }\end{array}$ & P \\
\hline Hearing impairments & 12,0 & 15,9 & 15,8 & 10,6 & ns. \\
\hline Vision impairments & 22,0 & 28,6 & 26,9 & 21,8 & ns. \\
\hline $\begin{array}{l}\text { Physical disability/motor } \\
\text { impairments }\end{array}$ & 12,0 & 15,7 & 14,4 & 12,0 & ns. \\
\hline $\begin{array}{l}\text { Speech disability, speech } \\
\text { impairments }\end{array}$ & 10,0 & 17,0 & 16,7 & 13,4 & ns. \\
\hline Difficulties with reading & 38,0 & 33,2 & 24,8 & 12,5 & 0,000 \\
\hline Difficulties with writing & 40,0 & 28,1 & 23,0 & 15,3 & 0,000 \\
\hline Difficulties with counting & 44,0 & 36,8 & 22,0 & 16,7 & 0,000 \\
\hline $\begin{array}{l}\text { I make friends hard, I don't like } \\
\text { to talk or play with others }\end{array}$ & 22,0 & 18,9 & 17,2 & 7,9 & 0,002 \\
\hline
\end{tabular}

Source: own data collection

In the case of impairments deriving from organic origin, significant differences are not identified i.e. they do not affect students' academic achievement or their academic outcomes ${ }^{4}$, but quite surprisingly, there is a slight jump in the case of students with average school performance. There are significant differences in

\footnotetext{
${ }^{4}$ To the interpretation of academic achievement and outcomes See: Pusztai-Kovács 2015; Szemerszki 2015.
} 
learning disabilities, which are linear; therefore the better the learners are, the lower the proportion of the students' partial learning disorder is. It raises several questions: if learning disorder does not derive from physiological origin but (by definition) it has been formed as a result of any life event, the chances of improving students' partial ability disorders may be reduced or increased by the academic outcomes. Special pedagogy tends to say yes to this, as there are therapeutic, didactic tools for the treatment of learning disorder (Bodrogai et al. 2012), and the data in Table 3 confirm this, as relatively high indicators can be seen even among the very good students. Examining the issue from a sociological viewpoint, this linear relationship seems to be worrying, as four tenths of students with lower than the average school performance (academic outcomes) are involved. This refers to the reproduction of inequalities, as well as to a hen-egg dilemma to decide what was earlier, the partial ability disorder or the bad (worse) academic outcomes. As we have pointed out, our research findings show that selfesteem and social support are increased by 'school successes, while exclusion is reduced by them, which can provide a way to increase self-esteem and the social support for students' with learning disabilities, and reduce their potential exclusion. Let us see this by examining the whole sample (Table 4).

Table 4: Do you have a problem that makes difficult for you to study and go to school - by successes (more options to select - \%)

\begin{tabular}{|l|c|c|c|}
\hline & $\begin{array}{c}\text { No problems } \\
\text { but success }\end{array}$ & $\begin{array}{c}\text { Problems } \\
\& \text { success }\end{array}$ & $\mathrm{P}$ \\
\hline Hearing impairments & 57,4 & 48,1 & $\mathrm{~ns}$. \\
\hline Vision impairments & 57,8 & 50,9 & $\mathrm{~ns}$. \\
\hline Physical disability/motor impairments & 57,3 & 48,1 & 0,002 \\
\hline Speech disability, speech impairments & 56,8 & 52,0 & $\mathrm{~ns}$. \\
\hline Difficulties with reading & 60,2 & 43,9 & 0,000 \\
\hline Difficulties with writing & 58,4 & 48,5 & 0,011 \\
\hline Difficulties with counting & 59,5 & 46,8 & 0,001 \\
\hline $\begin{array}{l}\text { I make friends hard, I don't like to talk or } \\
\text { play with others }\end{array}$ & 57,6 & 47,7 & 0,012 \\
\hline
\end{tabular}

Source: own data collection

In a relevant open question, school success is interpreted by students as success in academic and sports achievement, participation in competitions and quizzes, i.e. academic outcomes and school performance are interpreted as 'success'. The data in Table 5 show that school success is mentioned by almost a half of 
the students with learning difficulties, and between the two groups, and although a larger difference is observed, there is no significant distance in terms of school success. Among the disabilities deriving from organic origin, a significant difference can be observed between the two groups in the case of physical disabilities/motor impairments, which can probably be explained by their barriers in participating in sports. There are significant differences in the field of learning disabilities, which tend to influence school success. In order to interpret the results, a reference should be made to what we have already stated. These are neither disabilities nor learning disabilities that experts diagnose, but rather phenomena that students themselves experience as problems. The importance of school success and its relationship between the participation-frequency of learning problems is indicated plastically by the SEN variable created to present the participation-frequency and co-occurrence of the different learning problems (Table 5).

Table 5: The participation frequency of SEN and school success (\%)

\begin{tabular}{|l|c|c|c|}
\hline & Success & No success & Full sample \\
\hline No SEN problems & 51,1 & 39,3 & 45,8 \\
\hline One SEN problem & 18,3 & 20,9 & 19,5 \\
\hline More SEN problems & 16,7 & 21,1 & 18,6 \\
\hline $\begin{array}{l}\text { SEN and BPLD } \\
\text { problems }\end{array}$ & 11,9 & 16,5 & 14,0 \\
\hline BPLD problems & 2,0 & 2,2 & 2,0 \\
\hline Total & 605 & 460 & 1080 \\
\hline
\end{tabular}

Source: own data collection; $P=0,029$ (lack of response, $n=14$ )

According to the research, school success bears an outstanding importance for the self-esteem of and social support for students. Not only did self-esteem and social support increase and exclusion reduce by school success, but also success had an outstanding relationship with learning problems and disorders. The participation-frequency in school success is fewer among those who have mentioned any kind of problems, which means that the chance to experience school success is reduced by learning problems or disorders. At the same time, as it has been emphasized before, there is no significant distance related to the chance for school success among the students who have special educational needs or those who do not need them. The context also works vice versa, i.e. if school is able to provide success, SEN students' have the chance to obtain 
success due to self-esteem, social support, and inclusion. The results show that because of the 'phenomena' of SEN students are not excluded from obtaining and experiencing 'successes' in their own schools. The following table (Table 6) shows the basic distribution by country of the aggregated SEN variable by frequency.

Table 6: The frequencies of SEN problems - by country (\%)

\begin{tabular}{|l|c|c|c|c|}
\hline & Transcarparthia & Poland & Hungary & Total \\
\hline No SEN problems & 40,0 & 25,7 & 59,4 & 46,2 \\
\hline A SEN problem & 21,4 & 17,5 & 19,4 & 19,4 \\
\hline More SEN problems & 17,5 & 34,2 & 11,1 & 18,3 \\
\hline $\begin{array}{l}\text { SEN and BPLD } \\
\text { problems }\end{array}$ & 18,9 & 22,3 & 7,4 & 14,0 \\
\hline BPLD problems & 2,1 & 0,4 & 2,7 & 2,0 \\
\hline Total & 100,0 & 100,0 & 100,0 & 100,0 \\
\hline $\mathrm{n}$ & 280 & 269 & 552 & 1101 \\
\hline
\end{tabular}

Source: own data collection, $P=0,000$

As it was indicated, the Polish data are 'behaving' outstandingly, which was explained by the geographical, demographic as well as the educational characteristics of the Polish schools involved in the research, which is related to the sampling method. Having examined the Hungarian schools, there are significant differences between the students of the Hungarian-speaking ethnic schools in the motherland and Transcarparthia, since the Transcarparthian students can be characterized by higher SEN indicators. This is also explained by the sudents' family background and ethnic distribution from here: the proportion of poor families with low status is much higher, parents' education is low and the proportion of multiple disadvantaged Roma students is also high (Cséke-Fónai 2018). According to the SEN definition of OECD and the Public Education Act, the third group of the students involved in the research are the disadvantaged students, whose special educational needs are primarily due to socio-economic, cultural and/or linguistic factors (Mesterházi 2006). The Transcarparthian data seem to be explained by these factors. The sample of the data collection here, compared to the other two subsamples, reflects particularly the characteristics of the students' basic population. In addition to the distribution of the aggregated SEN indicators by country, there are also 
significant differences between the values of the subscales of QSL (Figure 1 All the three values of Chi-square test is $\mathrm{P}=0,000$ ).

Figure 1: Averages of QSL subscales in each student subsample

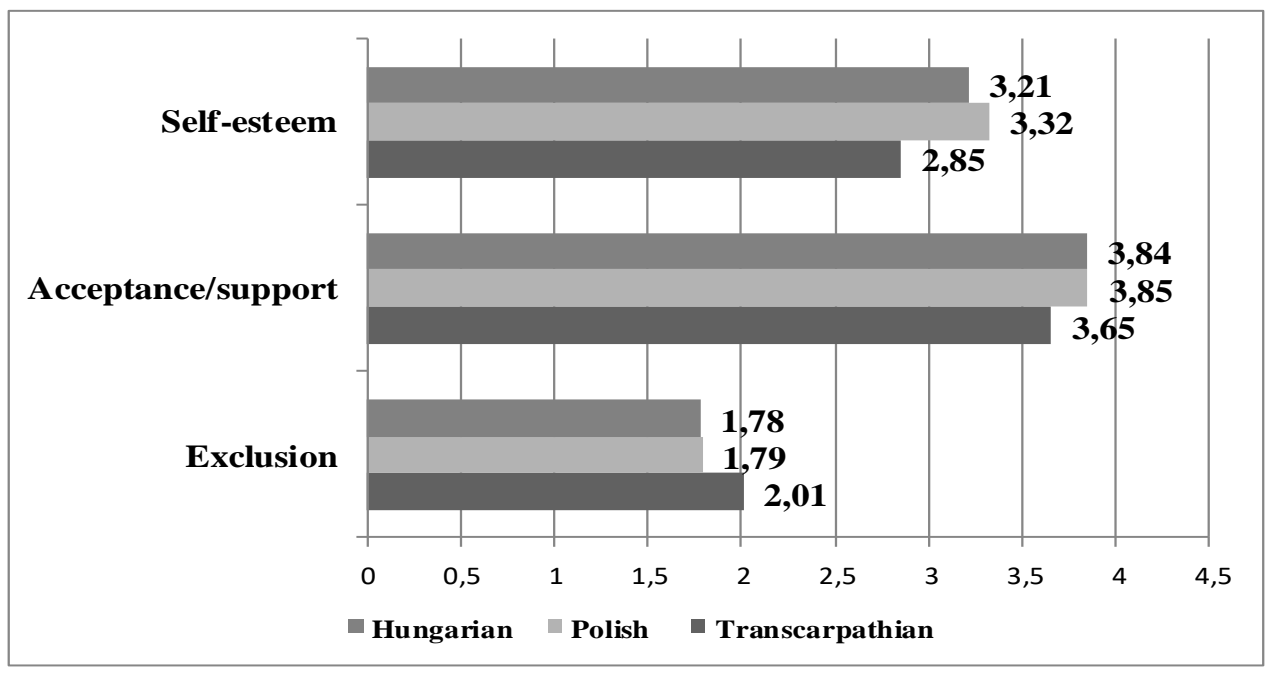

The values of the QSL subscales show that the Polish and the Hungarian students evaluated their own situation almost similarly, with one exception; the Polish students ranked themselves with higher values on the subscale of selfesteem. It was explained in one of our presentations comparing the Polish and the Hungarian data by the fact that the Polish school system was considered less selective during data collection, the degree of competition is lower, and more experience of successes are provided for students, which increase selfesteem, social acceptance and support (including students with SEN) (FónaiHüse 2017). In the case of the Transcarparthian students, lower values can be experienced regularly, acceptance/support is relatively close to the values of the students from the other two samples, the value of the subscale of selfesteem is very low, and the exclusion perceived by students is high. This subscale is reversed, so lower indicator stands for lower exclusion. It complies with what earlier has been said about the SEN from several viewpoints, as Transcarparthian students come from lower status families and the proportion of students with Roma identity is high. At the same time, the relationship between SEN and the subscales of QSL only partially confirms what has been said before, (Figure $2-$ All the three values of Chi-square test is $\mathrm{P}=0,000$ ) i.e. the correlations tend to prevail between the subscales, indicating a general 
mechanism that can be significantly formed by the effect of different (explanatory) variables.

Figure 2: Relationship between the subscales of QSL and the participation frequency of SEN in the whole sample (five-point scale average)

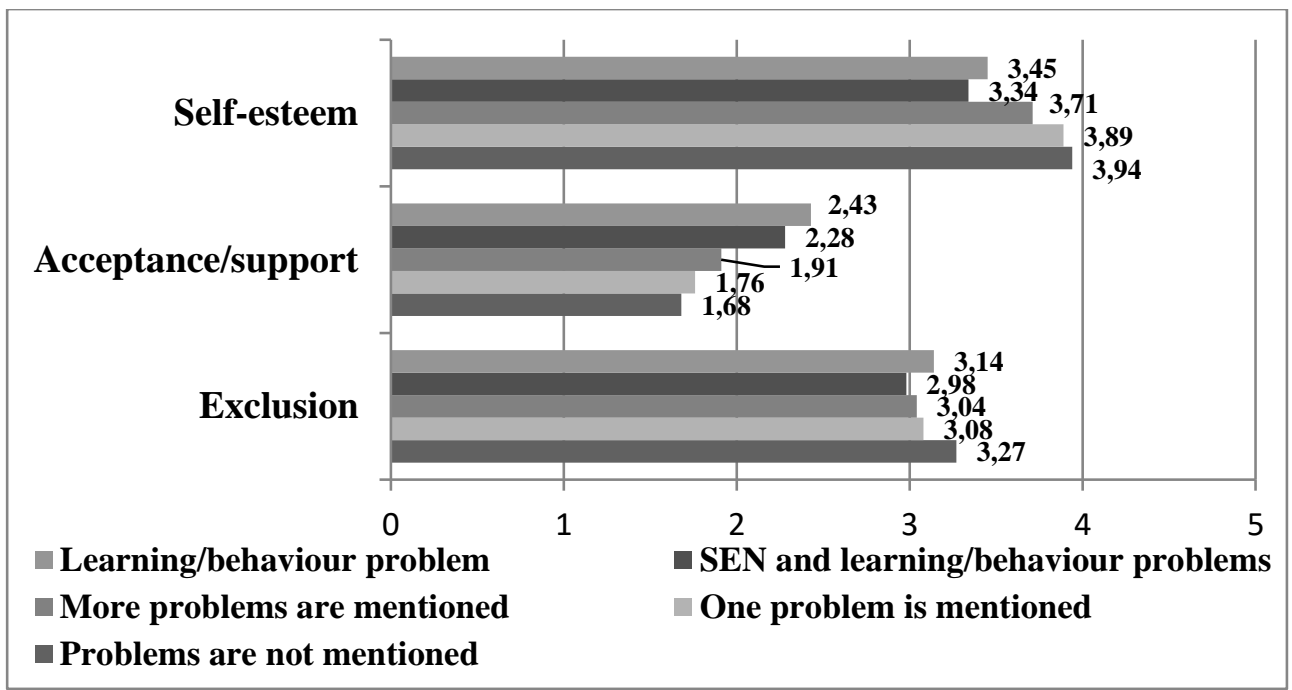

According to school successes, we argued that there is no unmanageable distance between SEN and majority students. The values of the subscale of self-esteem in the groups - based on the participation frequency of SEN - show that, apart from BPLD, linear relationship can be observed between the participation frequency of SEN, BPLD and self-esteem, i.e. SEN reduces the students' self-esteem. The situation is similar concerning the terms of acceptance and support, less support has been experienced by students in the classroom if they have SEN problems. In particular, this effect is enhanced in the subjective perception of exclusion, where perceived exclusion is increased specifically by BPLD. However, the facts mentioned do not question the statements about school performance and success, therefore it can be said that while acceptance and self-esteem is reduced by SEN, at the same time school performance and success related to it still increases SEN students' chances for classroom inclusion. 


\section{Conclusions}

In our study, the relationship between special educational needs and inclusion was analyzed based on the results of an international research. In our previous writings, we focused primarily on factors influencing school and classroom inclusion, and we found - based on the values of the subscales of QSL - that school performance and success have a significant impact on acceptance, support, and self-esteem while they reduce the exclusion perceived by students. It seems that this mechanism works indeed, but its validation for students with SEN is controversial. There is no unmanageable distance in school success between students who subjectively perceive SEN symptoms and the majority of students, therefore the golden gate is seemingly open, as successes they have experienced support inclusion according to our previous results. In comparison, the results of our analysis of the entire international sample show that those students with one or more SEN symptoms are less accepted and supported by their peers and their self-esteem is lower, and it represents a linear relationship with the participation-frequency of SEN symptoms. At the same time, this ultimately does not question the chances for inclusion, as success at school that the students have experienced may be able to counteract this situation and increase the acceptance of and social support for students with SEN. This is also an area of potential therapy: students with SEN need to provide success in order to strengthen their inclusion and increase their self-esteem.

\section{References}

1. Andor Mihály (2001): Társadalmi egyenlőtlenség és iskola. Educatio, 1. szám, pp. 15-30.

2. Bánfalvy Csaba (2008): A mai integrációs folyamatok és azok elözményei. In: Bánfalvy Csaba (szerk.) Az integrációs cunami. Tanulmányok a fogyatékos emberek iskolai és társadalmi integrációjáról. Budapest: ELTE Bárczi Gusztáv Gyógypedagógiai Főiskola Kar ELTE Eötvös Kiadó, pp. 11-43.

3. Balogh Erzsébet, Hüse Lajos (2017): Az iskolai közérzet és a rizikómagatartás egyes aspektusainak összefüggései. In: Fábián Gergely, Szoboszlai Katalin, Hüse Lajos (szerk.) A társadalmi periférián élő gyermekek és fiatalok rizikómagatartásának háttere. Nyíregyháza: Periféria Egyesület, pp. 91-112.

4. Bodrogai Tibor, Soltész Éva, Pápay Nikolett, Vaskó Györgyné (2012): A sajátos nevelési igény pedagógiája - pszichológiája. In: Bodrogai Tibor 
(szerk.) Sajátos nevelési igényűek pedagógiája és pszichológiája. Budapest: Pázmány Péter Katolikus Egyetem Vitéz János Kar, pp. 38-108.

5. Csányi Yvonne (2001): Különtámogatás: szegregáltan vagy integráltan. Trendek külföldön és Magyarországon. Educatio, 11 évfolyam, 2. szám, pp. 232-243.

6. Csányi Yvonne (2008): Új utak és törekvések az SNI-tanulók oktatása terén. In: Bánfalvy Csaba (szerk.) Az integrációs cunami. Tanulmányok a fogyatékos emberek iskolai és társadalmi integrációjáról. Budapest: ELTE Bárczi Gusztáv Gyógypedagógiai Főiskola Kar ELTE Eötvös Kiadó, pp. 65-74.

7. Cséke Katalin, Fónai Mihály (2018): A kezdet kezdetén: Kárpátaljai roma tanulók az iskolában. In: Torgyik Judit (szerk.): Néhány társadalomtudományi kutatás és innováció. Komárno: International Research Institute, pp. 204-212.

8. Farnicka, M.; Liberska, H.; Kosiková, V., Lovasová, V. \& Freundenreich, D. (2014): A New Tool in the Fight agains Social Exclusion: The Questionnaire of School Life (QSL). In: Liberska, H., Farnicka, M. (eds.) A Child of many Worlds: Focus on the Ethnic Minority Problem. Frankfurt am Main, Peter Lang. pp. 177-191.

9. Fejes József Balázs, Szűcs Norbert (2018): Én vétkem. Helyzetkép az oktatási szegregációról. Szeged: Motiváció Oktatási Egyesület.

10. Fónai Mihály, Hüse Lajos (2017): School integration, inclusion and exclusion: experiences of empirical researches. Challenge and/or chance - the integration of Romani (gypsy) people in Europe. Faculty of Child and Adult Education of the University of Debrecen, Hajdúböszörmény, pp. 24-25.

11. Fónai Mihály, Hüse Lajos (2018): Roma tanulók és az iskola: befogadás és kirekesztés. In: Endrődy-Nagy Orsolya, Fehérvári Anikó (szerk.) Innováció, kutatás, pedagógusok. Budapest: Magyar Nevelés-és Oktatáskutatók Egyesülete, pp. 600-611.

12. Hüse, Lajos, Balogh, Erzsébet, Barnucz, Nóra, Fónai, Mihály and Zolnai, Erika (2014): The Discourse of Social Exclusion and its Benefits for the Majority. In: Hanna Liberska and Marzanna Farnicka (eds.) A Child of Many Worlds: Focus on the Ethnic Minority Problem. Frankfurt: Peter Lang Verlag. pp. 47-66.

13. Hüse Lajos (2017): Az exklúzió és inklúzió szerveződési szintjei. In: Hüse Lajos, Molnár Erzsébet (szerk.) Fiatal felnőttek iskolai és társadalmi 
inklúziójának támogatása. Szakkollégiumi Tudástár 4. Nyíregyháza: Evangélikus Roma Szakkollégium, pp. 39-88.

14. Hüse Lajos, Horváth Cintia (2018): A rizikómagatartás implicit attitűdjeit befolyásoló egyes szocializációs tényezők vizsgálata mélyszegénységben és szakellátásban élő fiatalok körében. Esély. 6. pp. 107-132.

15. Hüse Lajos, Ceglédi Tímea (2018) „Érett dió is lehetek”. A megterhelő életesemények és a reziliencia hatása az iskolai pályafutásra. Szakkollégiumi Tudástár 5. Nyíregyháza. Evangélikus Roma Szakkollégium.

16. Kertesi Gbor, Kézdi Gábor (2012): A roma és nem roma tanulók teszteredményei közti különbségekről és e különbségek okairól. Budapesti Munkagazdaságtani Füzetek 5. Budapest: MTA Közgazdaság-és Regionális Tudományi Kutatóközpont Közgazdaságtudományi Kutatóintézet, Budapesti Corvinus Egyetem Emberi Erőforrások Tanszék.

17. Mesterházi Zsuzsanna, Gereben Ferencné (2006): A (gyógy)pedagógiai diagnosztikai alapfogalmak: a tanulás és a tanulási sikertelenség alapértelmezése. (Gyógy)pedagógiai diagnosztika és tanácsadás. In: Zsoldos Márta (szerk.) (Gyógypedagógiai diagnosztika és tanácsadás: Kézikönyv a nevelési tanácsadókban, szakértői és rehabilitációs bizottságban végzett komplex vizsgálathoz. Budapest, Magyarország: Oktatási Minisztérium, Fogyatékos Gyermekek, Tanulók Felzrkóztatásárt Országos Közalapítvány, pp. 22-47.

18. Mesterházi Zsuzsa (2007): Változik-e a gyógypedagógia identitása? Iskolakultúra, 17. évfolyam, 6-7. szám, pp. 150-163.

19. Papp Gabriella (2002): Tanulásban akadályozott gyermekek iskolai integrációja a szakemberek közötti kooperáció tükrében. Magyar Pedagógiai Szemle 102. évfolyam, 2. szám, pp. 159-178.

20. Papp Gabriella (2012): Az integráció, inklúzió fogalmak tartalmi elemzése gyógypedagógiai megközelítésben nemzetközi és magyar színtéren. Gógypedagógiai Szemle, 40. évfolyam, 3. szám, pp. 295-304.

21. Pető Ildikó (2003): Inklúzió a nevelésben. Iskolakultúra 10. évfolyam, 10 szám. pp. 3-12.

22. Pető Ildikó, Ceglédi Tímea (2012): A pedagógusok SNI-vel szembeni attitüdje SACIE-vel mérve. Iskolakultúra, 12 évfolyam, 11. szám, pp. 66-82.

23. Peace, R. (2001): Social Exclusion: A Concept in Need of Definition? Social Policy Journal of New Zealand 16: pp. 17-35. 
24. Pongrácz Kornélia (2013): Többségi általános iskolások sajátos nevelési igényü gyerekekkel szembeni attitüdjének vizsgálata. Gyógypedagógiai Szemle, 41 évfolyam, 3. szám.

25. Pusztai Gabriella, Kovács Klára (2015): Ki eredményes a felsőoktatásban? Nagyvárad - Budapest: Partium Kiadó Új Mandátum Kiadó

26. Rodgers, G. (1995): What is special about a social exclusion approach? In: Rodgres, G., Gore, C. \& Figueiredo, J. (eds.) Social Exclusion: Rhetoric, Reality, Responses. International Institute for Labour Studies, Geneva, pp. 43-55.

27. Schiffer Csilla (2008): Az inklúzió fogalmának értelmezései és azok ellentmondásai. In: Bánfalvy Csaba (szerk.) Az integrációs cunami. Tanulmányok a fogyatékos emberek iskolai és társadalmi integrációjáról. Budapest: ELTE Bárczi Gusztáv Gyógypedagógiai Főiskola kar ELTE Eötvös Kiadó, pp. 45-63.

28. Szabó Diána (2015): A fogyatékossággal élő személyekkel kapcsolatos holisztikus megközelítések kialakulásának összefüggései. Magyar Pedagógia, 115. évfolyam, 4. szám, 319-342.

29. Szemerszki Mariann (2015): Eredményesség az oktatásban. Budapest: OFI 30. Zolnai Erika, Balogh Erzsébet, Barnucz Nóra, Fónai Mihály \& Hüse Lajos (2016): Lehetőség, kihívás vagy akadály? A közoktatás integrációs feladatai - nemzetközi kitekintés és magyarországi helyzetkép. Különleges Bánásmód, 2. évfolyam, 2. szám, pp. 5-21.

31. Zolnai Erika, Fónai Mihály, Hüse Lajos Balogh Erzsébet \& Barnucz Nóra: A településtípus és méret lehetséges hatása az iskolai integrációra és inklúzióra. HuCER 2016. május 26-27. Kaposvári Egyetem. 